\title{
The Origin and Artistic Style of Ceramic Art in the Song Dynasty
}

\author{
Hongshan Chen \\ Henan University of Technology \\ Zhengzhou, China
}

\begin{abstract}
Ceramic art is an important part of the development of Chinese nation and forms artistic characteristics of different times. Song dynasty is the booming period Chinese porcelain making craft. The art of products has reached highly skilled condition. Porcelains made in Song dynasty have extraordinary decorative art and pay attention to the combination of utility and aesthetics, creatively combine Chinese ceramic art with the art of painting and calligraphy to form ceramic art that has rich cultural connotation.
\end{abstract} style

Keywords - the Song Dynasty; porcelain art; origin; artistic

\section{INTRODUCTION}

China is one of the few countries with ancient civilizations in the world and has made enormous contribution for the development of human society; especially the achievements on ceramic art have great significance. Chinese ceramic technology can be traced back to $4000 \mathrm{BC}$ to $2000 \mathrm{BC}$. Ceramic art is an important part of the development of Chinese nation. The pursuit of beauty of Chinese people is embodied through porcelain making craft to a large extent and forms artistic characteristics of different times. Song dynasty is the booming period of Chinese porcelain making craft. At that time, a large number of porcelains are output to Europe and many countries in southeastern Asia. The Ming kiln represented by Ding kiln, $\mathrm{Ru}$ kiln and Jun kiln springs up throughout the country. The products have reached highly skilled condition. Porcelains made in Song dynasty have extraordinary painting and decorative arts and pay attention to the combination of utility and aesthetics; creatively combine Chinese ceramic art with the art of painting and calligraphy to form ceramic art that has rich cultural connotation.

\section{ORIGIN AND CHARACTERISTICS OF THE} DEVELOPMENT OF CERAMIC ART IN SONG DYNASTY

\section{A. Development of Ceramic Art Before Song Dynasty}

Before Europeans grasp the porcelain making craft, Chinese people are highly skilled in making quite delicate ceramic technology. From the development history of Chinese ceramic, ceramic mainly includes "pottery" and "porcelain". Generally speaking, pottery refers to the clay that the matrix isn't sintered and products of porcelain stone. The part that the sintering temperature is higher is called hard pottery and the ceramic that adds glaze is called glazed pottery. The development of Chinese traditional ceramic has experienced rather long developing process. In primitive society, people carve exquisite pattern on the utensils used in hunting and fishing to appreciate. From the period of Yellow Emperor to Xia dynasty, it is mainly marked by the development of ancient painted pottery, which is represented by Yangshao culture and Majiayao culture, etc. In the early 1950s, a large number of exquisite ancient painted pottery products are excavated in Banpo Remain. During Western Zhou Dynasty, China begins to fire the first generation of original ceramic and the ceramic technology in this period has close relationship with politics and culture. During the period of Shang Dynasty, class society comes into being. Slaveholders become the owners of all property. In order to show their social status, they decorate patterns on ceramics in this period, which lay an important foundation for the subsequent development of ceramic art. In grand unification epoch, except for utensils used in daily life, utensils used in worship ceremony also develop to a large extent. During the period of Han dynasty, artists continuously enrich materials of ceramic creation. At that time, most ceramic materials are on longer jade articles and metals. The ceramic firing technology gets rapid improvement. The solid and pyknotic glazed pottery appears. The Chinese character "Ci" comes into being. [1]70 Besides, Central China open the trade route to Syria via Sinkiang and Persia and it begins with the trade contacts with Roman Empire. Ceramic technology in this period is also deeply influenced by foreign culture. During the Six Dynasties, Buddhism begins to spread widely throughout the country. Buddhism art has certain influence on ceramic at that time, especially reflecting on the modeling of ceramic works. Tang Dynasty is called the important period of porcelain making craft. The technology of porcelain making has improved greatly. A large number of porcelains appear and truly open the era of high quality porcelains.

\section{B. Characteristics of Chinese Traditional Ceramic Art}

The ceramics in Xia and Shang dynasties in ancient China are mainly embodied in the kind of ceramic excavated in $\mathrm{Y}$ in $\mathrm{Xu}$ and its ceramic art is mainly reflected on ceramic decoration. The emblazonry, words and symbols on it have close relationship with inscriptions on bones or tortoise shells of Shang Dynasty at that time. With the development of porcelain making craft in Shang dynasty, it appears the 
glazing porcelain making craft, which is widely used by common people. We can research the ceramic culture during Qin and Han dynasty by inspecting the potteries remained in the ruins, at the same time exploring architectural structure and mode at that time. During Tang dynasty, the ceramic making craft is relatively mature. It truly enters the era of porcelain. The division of porcelain is mainly based on the firing temperature and texture. Because the temperature of firing porcelain is not high in Han dynasty, the yielding porcelain is relatively fragile. In Tang dynasty, the glazing porcelain craft develops gradually and the firing temperature reaches above $1000{ }^{\circ} \mathrm{C}$. At that time, the kilns used to fire porcelain mainly have Yue kiln, Xing kiln, which mark the new level of porcelain making craft during Tang dynasty. The ceramic art in Song dynasty best represents the pottery making craft. Song dynasty becomes the peak of the development of Chinese ceramic art and enjoys a good reputation both at home and abroad. The ceramic kilns at that time mainly have Ru kiln, Jun kiln and Guan kiln. The porcelains made in Song dynasty have solid texture and beautiful appearance and truly reach the realm of outstripping history. In Song dynasty, new porcelain craft is developed. For example, the underglaze uses red and blueand-white color, which makes colored pottery become the main current of ceramic art at that time. Especially the development of white porcelain surpasses other kinds of porcelain. Ceramic culture in Song dynasty is mainly white porcelain, which has obvious difference from previous celadon. Blue-and-white porcelain and porcelain with five colors are the mainstream products of porcelain at that time. Jingdezhen becomes the production center of porcelains and its scale is also the largest at that time and has continued for hundreds of years. Porcelains of Jingdezhen base on natural materials, and make ceramic art extraordinary and infuse new blood into the Chinese long-standing ceramic art. With the development of external exchange in Song dynasty, folk kilns in various regions develop rapidly and a large number of porcelains are exported, which enrich the ceramic culture at that time.

\section{SOCIAL BACKGROUND AND CONDITIONS OF THE FORMING OF CERAMIC ART IN SONG DYNASTY}

\section{A. Forming of Civil Culture and Aesthetic Thought in Song Dynasty}

The establishment of Song dynasty ends the long-term chaotic social situations. Governors at that time implement the policy of putting mental pursuits above material arts, which make the society become more stable and economy flourish and develop, especially the civic culture obtains unprecedented development. It records in Dongjing Menghua Record that: "a flourishing scene of prosperity; fragrant hill and wine shops; alleys lead to a secluded quiet place; more than ten thousands of restaurants for banquets and places for singing and dancing; no empty big and small stores; brokerage houses are often more than hostels." [2] 104 In addition, the scene of Bianliang, the capital of Song Dynasty, described in Zhang Zeduan's Riverside Scene at Qingming Festival means that with the prosperity of urban economy, people have more leisure time after work. In this way, some recreational activities appear in citizen stratum. The painting and decorative arts of ceramics in Song dynasty are the vivid embodiment of these contents. One important characteristic of the development of civic culture is the commercialization of recreation, such as the emergence of crossing railing and tile house greatly enrich the content of ceramic painting and decoration. For example, in the circus picture with white ground and black flowers, there are some scenes of acrobatic performance. A person stands upside down on the galloping horseback, and it gives people heartstopping feeling. Besides, with the mass production and popularity of ceramic in Song dynasty, its decorative contents also reflect the aesthetic thought of common people. It takes root in Chinese traditional esthetic concept. Over two thousand years of Chinese traditional culture makes people have boundless yearning for good life and form a kind of positive and optimistic esthetic sentiment. These esthetic sentiments are also reflected on the artistic style of ceramics of Song dynasty and they take obvious secularity. For example, in the decoration of ceramics of Song dynasty, beasts of prey such as tiger, lion and bear often appear. It represents people's good wishes to counteract evil force and get rid of evil by using their ferocity. There are some themes of children play, because child is the continuation of life as well as people's hope.

\section{B. Artistic Condition of the Forming of Ceramic Art in Song Dynasty}

Ceramic art in Song dynasty that has decorative style of wash painting can develop and flourish only with perfect artistic condition and combination of esthetic sentiment at that time and it finally reaches the peak in Song dynasty. At that time, Song dynasty is rich in Daqing clay and hargil and a large number of white alkalis used to make engobe. Materials used to paint spotted stone also exist here. Furthermore, the coal production craft in Song dynasty also obtains great improvement, which provide sufficient fuels for ceramic firing and many ceramic kilns are located near to coal mine. For example, in the period of Emperor Huizong of Song Dynasty, people use coal as fuel instead of traditional firewood. This is because coal can make the temperature in the kiln rise slowly and oxidize the glaze into white color and replace the turquoise formed by burning firewood. During the Northern and Southern Dynasties, ceramic artists at that time have begun to fire white porcelain of engobe. In Song dynasty, this kind of firing craft becomes mature gradually and lays important foundation for the forming of ceramic art. Meanwhile, during Sui dynasty, the colored drawing and decorative skills of glaze have certain development and it provides important reference for the development of ceramic art in Song dynasty. Since Sui dynasty, colored drawing craft of glaze has developed from traditional brown to two kinds of color, brown and green. The Changsha kiln at that time creatively uses writing brush to directly make freehand brushwork on matrix. This kind of technique of drawing is free and mainly uses brown lines. For example, the image of birds on the fragments that have painting of flowers and birds in Changsha kiln corresponds to the ripple in water to foil the theme. It reflects the real feelings of life and esthetic thought of commercial painters. 
The porcelain making art in Song dynasty uses this artistic technique of drawing for reference and combines with the local unique materials of spotted stone to decorate and has created decorative art of white ground and black drawings that the modeling is more rigorous and the emblazonry is more reasonable.

\section{Connotation And Style Of Ceramic ART IN SONG DYNASTY}

\section{A. Ceramic Art and Calligraphy and Painting of Scholars in Song Dynasty}

Most ceramics produced in Song dynasty are articles of daily use and become a popular kind of Chinese ancient porcelain. Porcelains of Song dynasty also have very high value of arts and crafts. As utensils used in daily life, porcelains have decorative pictures, which focus on reflecting the thoughts and stories of scholars at that time. The use of writing and words can show that ceramic art in Song dynasty is deeply influenced by thoughts of scholars at that time. Song dynasty is the prosperous period of culture and art. As a kind of arts and crafts, ceramic art reflects the esthetic thought at that time and is deeply influenced by genre painting in Tang dynasty at the same time. Calligraphy and painting of scholars in Song dynasty is a kind of painting style and show the spiritual and cultural ideological trend of "wideness of landscape". For example, the painting of manof-letters of Chen Heng has "put no time and energy in the observation and study of the painting, but make out the thoughts of scholars outside the painting." [3]17 "Learning of painting is not for others but to please himself" of Yao Chen becomes the center keynote of painting of man-ofletters at that time and is respectfully addressed as the purpose of painting by literati in Song dynasty. Most calligraphies and paintings of scholars in Song dynasty express scholars' aspiration. It pays attention to the temperament and interest of pen and ink and expressing artistic conception of calligraphy and painting. Scholars in Song dynasty particularly admire Su Shi and there are many poetries of Su Shi on porcelains. Porcelains in Song dynasty also appear the works that have the shape and structure of "Made by Hermit at the Riverbank of Zhanghe River" and its main emblazonry has landscape and people. This kind of works has outstanding features of literati painting in Song dynasty. Most painting styles on porcelains are scenes of life and stories of immortals at that time. On porcelains with words, they have certain profundity on grammar and ideological level expressed by it. Most of them are made by scholars personally at that time. Because of its value of arts and crafts, as presenting gift, porcelains in Song dynasty are endowed with certain cultural connotation. Writing poetries on porcelains is a kind of calligraphy decoration. The Changsha kiln that derives from Sui dynasty comes into vogue. Porcelains in Song dynasty create more plentiful calligraphic styles with various forms, which make the calligraphy decoration of porcelains in Song dynasty reach an unprecedented height on quantity and quality; and integrate the art of calligraphy and painting with the decorative art of porcelains. It not only has the content of poetic prose but also has pattern of manifestation of calligraphy, which form the unique artistic style of porcelains in Song dynasty.

\section{B. Culture and Style of Ceramic Art in Song Dynasty}

Porcelains in Cizhou kiln of Song dynasty focus on natural lingering charm and pursue natural beauty with rich emotion and have profound folk aesthetic ideology. The creation of its porcelains has rich vitality of folk life. Folk leisure and entertainment activities in Song dynasty mainly include sword dance, sumo, flap flags and kick the ball, etc. "Associations" of various folk leisure and recreation spring up continuously and make the folk leisure and recreation in Song dynasty have more sense of organization and greatly promote the development of folk leisure culture. Porcelains in Song dynasty mainly adopt the technique of freehand brushwork in traditional Chinese, and portray the scenes of activities in people's daily life. Its colors are mainly traditional black and white colors. This kind of painting and decorative art reflects thick folk characteristics and integrates simple and elegant ceramic art with rustic local characteristics. With the development of economy, porcelain artisans use porcelain as the carrier and infuse painting and calligraphy into it, which has promoted cultural levels and helped the sale of products. The decoration of porcelain in Song dynasty mainly uses painting techniques such as Chinese traditional outline drawing method and bone-free water ink portrait to show a true-life artistic characteristic. For example, the porcelain of "A Child Herds the Ducks" incisively and vividly portrays the child's clothing and postures and the ducks behind him. The painting has association of activity and inertia and shows the influence of true-life artistic style of painting in Song dynasty on the art of Cizhou kiln. [4]36 Ceramic art in Song dynasty mainly shows the folk tradition and fold customs in society at that time and has thick national customs. Influenced by general mood of society and the development of social economy in Song dynasty, the leisure and recreation culture on porcelains of Song dynasty has received great development on content and is well welcomed and loved by common people. Through leisure and recreation culture showed on porcelains, it can be seen that the ceramic art of Song dynasty has well kept the historical materials of national culture of Song dynasty and meanwhile has reflected the important position and influence of leisure and recreation culture in society at that time. Song dynasty is the golden age of the development of ceramic art. At that time, the opening degree of society is relatively high, Chinese and western cultures interact and infiltrate with each other and finally form bold and unrestrained and free artistic style, meanwhile it is also the reappearance of spiritual temperament of culture in Song dynasty.

\section{REFERENCES}

[1] Wang Dong. Research on Ceramic Decoration Art in Song Dynasty[J]. Ceramics Science and Art, 2007(2)

[2] Liu Zhiguo. Discussion on Artistic Creation Thought Embodied by Ceramics Made in Song Dynasty [J]. Ceramic Studies Journal, 2001 (3) 
[3] Zheng Quanfu. Discussion on Characteristics and Influence of Ceramic Art in Song Dynasty [J], Chinese Ceramics, 1986 (2)

[4] Zhao Dan. Research on Porcelain Pillow Art in Song, Jin, Yuan Dynasties [B], Master's Thesis in Minzu University of China, 2011 (5) 